\title{
Intermittent Irrigation Response Study Method of Rice Intensification System on Several Rice Varieties in The Physiology of Growth and Results of Rice
}

\author{
Hariyono \\ Department of Agrotechnonogy Faculty of Agriculture \\ Universitas Muhammadiyah Yogyakarta \\ Yogyakarta, Indonesia \\ hary@umy.ac.id
}

\author{
Bambang Heri Isnawan \\ Department of Agrotechnonogy Faculty of Agriculture \\ Universitas Muhammadiyah Yogyakarta \\ Yogyakarta, Indonesia
}

\begin{abstract}
A research aims to determine irrigation system and rice varieties that have the highest physiological growth and yield and to examine an interaction between plant varieties and irrigation systems on growth physiology and yield of rice plants. It was conducted at the Faculty of Agriculture, Universias Muhammadiyah Yogyakarta from May to August 2018. This study was arranged in a factorial 4x2 Randomized Complete Block Design with three replications. The first factor consisted of four rice varieties, i.e. Ciherang, Memberamo, Inpari-19, and Rojolele. The second factor consisting of two irrigation system, namely SRI and conventional methods. The results showed that the significantly highest crop harvest index was found in Ciherang variety in comparison to Inpari-19 and Rojolele. The highest weight of grain was significantly found in Rojolele variety in comparison to Inpari-19, Ciherang, and Memberamo and the lowest percentage of the unfilled grains was found in Ciherang variety in comparison to others. SRI irrigation method could result in the higher fresh weight growth and total root length compared to the conventional irrigation methods. The growth of the number of productive tillers, and the dry weight of plants within 12 weeks had a significant interaction between rice varieties and irrigation methods.
\end{abstract}

Keywords-Physiology, Rice Varieties and Intermittent Irrigation, SRI

\section{INTRODUCTION}

In Indonesia, rice does play an important role not only as a staple food, but also as an economic source of some rural communities. Production shortages affect various life aspects including social, economic and even political aspect. According to the 2014 BPS data [1], Indonesia's population of around 252.165 million requires around 53.6 million tons of dry milled grain per year, equivalent to 33.5 million tons of rice. National rice stock for the 2012/2013 period decreased from 7.4 to 6.48 million metric tons in the period of 2013/2014 representing 26\% decline within a 2 year period [2]. Therefore, the government must continue to strive to increase productivity and rice production intensively to stabilize rice prices. One of the causes of low rice production in Indonesia in general is related to the fact that farmers still cultivate rice not in accordance with the recommendations, such as tillage and the provision of fertilizer dosage not in accordance with the provisions and the domination of conventional systems. In conventional systems rice cultivation becomes wasteful in the use of water, where rice fields are continuously flooded leading to the decrease of the oxygen content in the soil and making photosynthesis system of rice less optimal only giving a $50 \%$ increase as expected [1]. Also, it causes root development disturbed, decreases in the number of total tillers and productive tillers and slows down harvest time.

In general, conventional seedling removal from the nursery is for the 20-30 -day-old seedlings with 5-7 seedlings even more perforated. The old seedling before being transferred to the land causes the seedlings to produce tillers while still in the nursery so that when the seedlings are removed the growth of the seedlings will be disrupted. The excessive planting seeds in one plant hole could cause competition, both in nutrients, light and space to grow so that the formed seedlings are not optimal [3].

In the last few years, one of the innovations developed was to match crops with the SRI (System of Rice Intensification) method. According to [4], with SRI cultivation rice production can increase by $78 \%$, save water requirements by $40 \%$ and save fertilizer by $50 \%$ and save of production costs by $20 \%$. [5] further explained that rice produced by SRI cultivation would be better than that of conventional rice cultivation. In SRI cultivation, rice plants have more tillers, more root growth and more number of grains per panicle. The development of rice planting patterns using the SRI method emphasizes on several main things, including the transfer of seedlings aged 8-15 days, spacing of $25 \mathrm{~cm} \times 25 \mathrm{~cm}$, not continuously inundated, planted with one seedling per planting hole and periodic irrigation [6].

The use of superior varieties in an area also determines the success factor of increasing rice production. Varieties to be tested using superior varieties were divided into 2 groups, namely hybrid and inbred. Varieties used included Ciherang, Memberamo, Inpari 19, and Rojolele. These types of variety determine the production results in each region, as well as environmental factors unsuitable for plant growth and development, for example: temperature, soil structure, soil type, and soil $\mathrm{pH}$. Both superior and local 
varieties have a different adaptability to the given cropping pattern; therefore, it is necessary to test the superior and local varieties with the SRI method of planting plans for intermittent and continuous flow, because of the environmental aspects, whether these varieties can grow and develop well and produce optimally at the place of testing.

In conventional systems wasteful rice cultivation is used in water, where in the system the fields are continuously flooded leading the oxygen content in the soil to decrease, indirectly affecting plant growth. In addition, it causes root development disturbed, decreases in the number of total tillers and productive tillers and slows down harvest time [3].

This study aims to determine the effect of irrigation on SRI and conventional methods on physiology, growth and yield on several rice varieties. The results of this study are expected to be useful for farmers to guide the technology of SRI method of rice cultivation in certain varieties in order to obtain the best growth and yield.

\section{METHODS}

The study was conducted in the experimental field of the Faculty of Agriculture Universitas Muhammaiyah Yogyakarta. The study was conducted from May to August 2018. The materials used for rice research included rice seeds of Ciherang, Memberamo, Inpari 19, and Rojolele varieties, farm manure, sand and regosol soil. The tools used included the Delta-Leaf Area Meter, Genesis UV Spectrophotometer, tractor, r, scales, and sprayer.

The method used in this research is a factorial $4 \times 2$ randomized complete block randomized block design. The first factor of variety (V) consisted of 4 levels, namely Ciherang, Memberamo, Inpari 19, and Rojolele and the second factor was irrigation (A) consisting of 2 levels, namely SRI and conventional methods with 8 treatment combinations repeated three times.

These treatments included:

Factor I variety $(\mathrm{V})$ consisting of 4 levels:

$$
\begin{aligned}
\text { V1 } & =\text { Ciherang } \\
\text { V2 } & =\text { Memberamo } \\
\text { V3 } & =\text { Inpari } 19 \\
\text { V4 } & =\text { Rojolele }
\end{aligned}
$$

Irrigation Factor II (A) consisted of 2 levels:

$$
\mathrm{A} 1=\text { intermittent irrigation }(\mathrm{SRI})
$$$$
\mathrm{A} 2=\text { continuous flooding (conventional) }
$$

Each experimental unit was a $3 \times 3.5$ m experimental plot with 3 sample plants. The parameters observed to determine the physiology of growth and yield of rice crops consisted of plant height $(\mathrm{cm})$, number of tillers, number of productive tillers (panicles), plant fresh weight (grams), plant dry weight (grams), and root length $(\mathrm{cm})$, Total root length, leaf area $(\mathrm{cm})$, panicle length $(\mathrm{cm})$, harvest index, grain weight per clump (gram), dry grain yield, and percentage of empty grain (\%). Observation data were analyzed using Anova (Analysis of variance) at the level of $\alpha=5 \%$. If there is a significant difference, further testing is used with Duncan Multiple Range Test (DMRT) at $\alpha=5 \%$.

\section{RESULTS AND DISCUSSION}

\section{A. Rice Plant Growth}

Table 1 shows the mean plant height, number of tillers, and fresh weight of rice plants aged 12 weeks. The results of variance in plant height, number of tillers, and fresh weight of plants showed no significant interaction between varieties and irrigation. Variety treatment, meanwhile, showed a significant growth in plant height, while the irrigation treatment showed no significant difference. The height of the rice plant between Rojolele and Inpari 19 variety showed no significant difference but both varieties

\begin{tabular}{|c|c|c|c|}
\hline Treatment & $\begin{array}{l}\text { Plant Height } \\
(\mathrm{cm})\end{array}$ & $\begin{array}{l}\text { Number of } \\
\text { tillers }\end{array}$ & $\begin{array}{c}\text { Fresh weight } \\
\text { of plant } \\
\text { (grams) }\end{array}$ \\
\hline Ciherang & $82,52 \mathrm{r}$ & $17,39 \mathrm{p}$ & $86,98 \mathrm{r}$ \\
\hline Memberamo & $89,04 \mathrm{q}$ & $17,51 \mathrm{p}$ & $238,36 \mathrm{q}$ \\
\hline Inpari19 & $98,07 \mathrm{p}$ & $17,03 \mathrm{p}$ & $269,47 \mathrm{pq}$ \\
\hline Rojolele & $98,68 \mathrm{p}$ & $18,44 \mathrm{p}$ & $312,81 \mathrm{p}$ \\
\hline$S R I$ & $93,08 \mathrm{a}$ & $16,02 \mathrm{a}$ & $266,02 \mathrm{a}$ \\
\hline Conventional & $92,06 \mathrm{a}$ & $14,56 \mathrm{a}$ & $189,68 \mathrm{~b}$ \\
\hline Interaction & $(-)$ & $(-)$ & $(-)$ \\
\hline
\end{tabular}
were significantly higher than that of the Memberamo and Ciherang varieties.

Table 1. Average plant height, number of tillers, and fresh weight of rice plants aged 12 weeks

Here, Memberamo variety was significantly higher than Ciherang variety. The difference in height of rice plants among varieties occurred as rice varieties have the unequal growth dependent upon the description of the variety. The height of rice plants with intermittent irrigation was not significantly different from the one with conventional irrigation/inundation. Rojolele variety had a high plant potential up to $\pm 123 \mathrm{~cm}$ and had an upright plant shape [7]

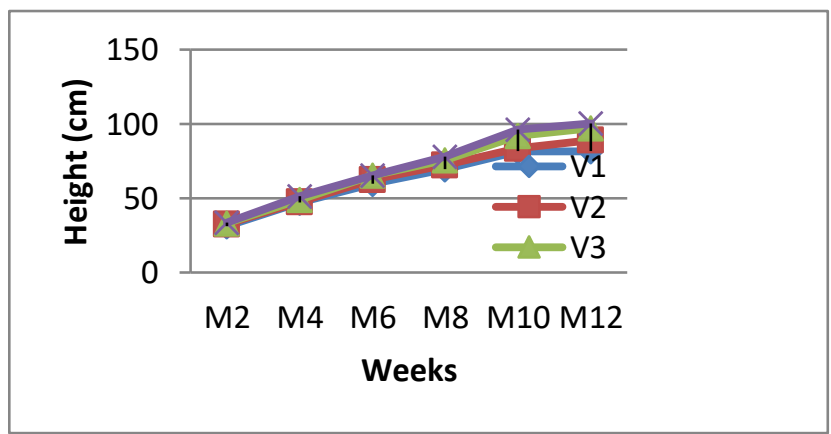

Figure 1 (a). Graph of Rice Crop Height

Figure 1 (a) shows that the high growth of Rojolele variety in the $19^{\text {th }}$ week and the $12^{\text {th }}$ week was relatively higher than that of the Memberamo and Ciherang varieties. This was because Rojolele variety had a longer lifespan enabling it to support the growth of plant height. Inpari 19 variety had high habitus according to the rice description. As seen in Figure 3 (b), the irrigation treatment at the site showed that the plant height was relatively the same as the one in conventional irrigation. Intermittent irrigation will 
not reduce plant height growth, meaning that intermittent irrigation will not inhibit the plant height.

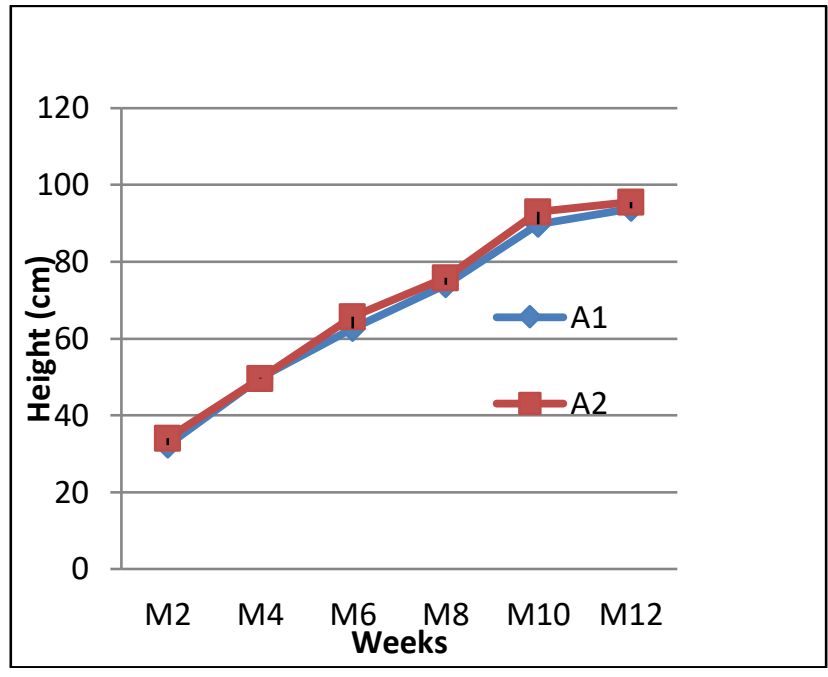

Figure 1 (b). Graph of Rice Crop Height

$$
\begin{array}{rlrl}
\text { Note: } \mathrm{V} 1 & =\text { Ciherang } & \mathrm{A} 1=\mathrm{SRI} \\
\text { V2 } & =\text { Memberamo } & \mathrm{A} 2=\text { Conventional } \\
\text { V3 } & =\text { Inpari } 19 & & \\
\text { V4 } & =\text { Rojolele } & &
\end{array}
$$

The results of variance in the number of tillers as shown in Table 1 showed the insignificant difference of the number of tillers in the treatment of varieties. Similarly, the irrigation treatment showed no significantly different effect. The number of tillers produced was between 15-18 tillers per rice plant. This is in line with the statement [2] that when compared to the existing superior varieties, the new types of rice differ in terms of stronger stems, greener and thicker leaves, medium tillers, and denser and heavier panicles.

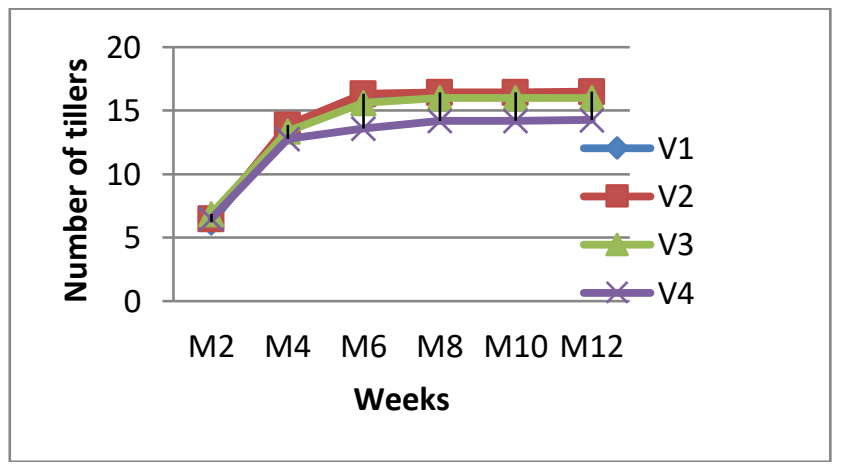

Figure 2 (a) Growth of Rice Plant

Figure 2 (a) shows that, started from $6^{\text {th }}$ week to $12^{\text {th }}$ week, the varieties of Ciherang, Memberamo, and Inpari 19 had a relatively higher number of tillers than the one in Rojolele varieties. Figure 2 (b) shows that, in terms of intermittent irrigation treatment, the total was relatively higher than that of conventional irrigation as seen in $2^{\text {nd }}$ week 2 to $12^{\text {th }}$ week. This showed that intermittent irrigation has resulted in the relatively more number of rice tillers, so that the yield of seedlings obtained would be relatively more

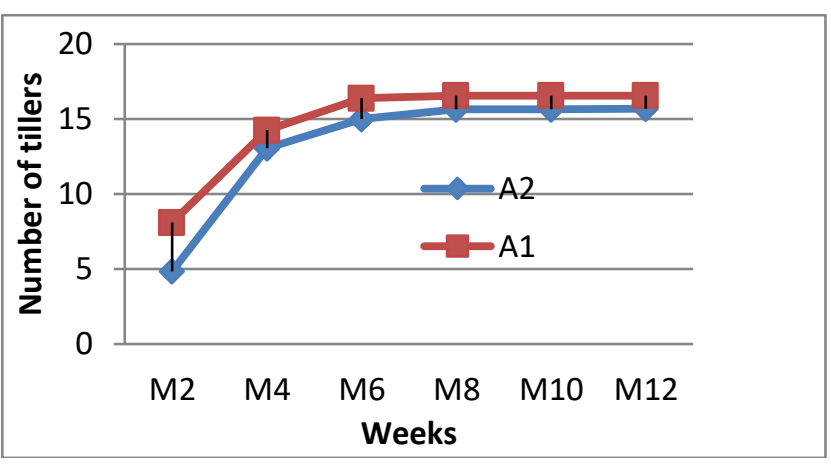

Figure 2 (b) Growth of Rice Plant

$$
\begin{array}{rlrl}
\text { Note: } V 1 & =\text { Ciherang } & & \text { A1 }=\text { SRI } \\
\text { V2 } & =\text { Memberamo } & \text { A2 }=\text { Conventional } \\
\text { V3 } & =\text { Inpari } 19 & & \\
\text { V4 } & =\text { Rojolele } & &
\end{array}
$$

The results of the variance in fresh weight of rice as shown in Table 1 showed some significant differences between the treatments of varieties. Similarly, the irrigation treatment showed some significant differences. Rojolele variety showed the higher fresh weight of real plants compared to Memberamo and Ciherang varieties. The Memberamo variety, meanwhile, showed the higher fresh weight of real plants compared to Ciherang. The plant growth depends on the interaction between plants and their environment [11]. The SRI method showed the higher fresh weight than that of conventional methods, namely 260.08 grams and 198.66 grams, respectively. Intermittent irrigation with less amount of water will be effectively absorbed by plants.
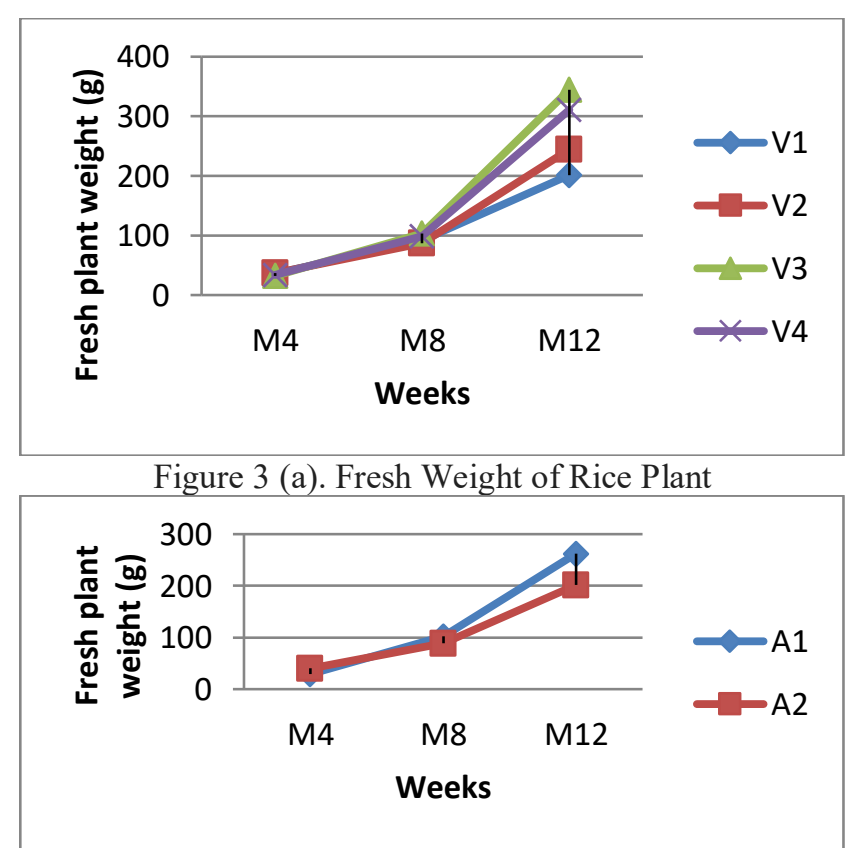

Figure 3 (b). Fresh Weight of Rice Plant

$$
\begin{aligned}
\text { Note: } & \text { V1 }=\text { Ciherang } \\
\text { V2 } & =\text { Memberamo } \\
\text { V3 } & =\text { Inpari } 19 \\
\text { V4 } & =\text { Rojolele }
\end{aligned}
$$

$$
\begin{aligned}
& \mathrm{A} 1=\mathrm{SRI} \\
& \mathrm{A} 2=\text { Conventional }
\end{aligned}
$$


Figure 3 (a) shows the increase in the growth of fresh rice weight from the $4^{\text {th }}, 8^{\text {th }}$ and $12^{\text {th }}$ weeks of various varieties. In the $12^{\text {th }}$ week the Inpari 19 variety showed a relatively higher fresh weight growth, while the Ciherang variety showed relatively low one. This was because the age of Ciherang rice variety is relatively shorter i.e. 100-day plant life [2] compared to other varieties. Figure 5 (b) shows that, in intermittent irrigation treatment at week 12, the growth of fresh weight was relatively higher as compared to the one in conventional treatment.

The results of the variance in rice dry weight as shown in Table 2 showed a significant interaction between varieties and irrigation. Inpari 19 variety with SRI intermittent irrigation showed the most severe dry weight of rice, significantly heavier than Memberamo, Inpari 19, and Ciherang varieties with conventional irrigation, and Ciherang with SRI irrigation. This showed that Inpari 19 variety with SRI intermittent irrigation was mostly efficient in producing the dry weight of plants. The production of plant dry weight depends on absorption, sun exposure and $\mathrm{CO} 2$ and water extraction [7].

Table 2. Average dry weight of 12 -week old rice plants

\begin{tabular}{llllll}
\hline $\begin{array}{c}\text { Treat- } \\
\text { ment }\end{array}$ & Ciherang & $\begin{array}{c}\text { Membe- } \\
\text { ramo }\end{array}$ & Inpari19 & Rojolele & Average \\
\hline$S R I$ & $32,93 \mathrm{~d}$ & $\begin{array}{l}58,26 \\
\mathrm{abc}\end{array}$ & $65,95 \mathrm{a}$ & $59,84 \mathrm{ab}$ & 54,25 \\
$\begin{array}{l}\text { Conven- } \\
\text { tional }\end{array}$ & $37,95 \mathrm{~d}$ & $52,26 \mathrm{bc}$ & $50,45 \mathrm{c}$ & $61,84 \mathrm{ab}$ & 50,63 \\
\hline Average & 35,44 & 55,26 & 58,20 & 60,84 & $(+)$ \\
\hline
\end{tabular}

Note: Numbers followed by the same letter in one row and columns show no significant difference based on F-test and continued with DMRT at level $\alpha=5 \%$.

$(+)=$ there is interaction between the treatment of varieties and irrigation

As shown in Figure 4 (a), in the $12^{\text {th }}$ week, the treatment of Rojolele variety, Inpari 19, and Memberamo showed the relatively higher growth of plant dry weight than that of Ciherang variety. In Figure 6 (b), it can be seen that the treatment of SRI showed that dry weight growths at weeks 4, 8 and 12 were relatively similar to the one in conventional irrigation, but at 12 weeks the SRI intermittent irrigation produced the relatively higher dry weight compared to the conventional irrigation. This showed that the intermittent irrigation could increase the rate of photosynthesis as such irrigation could create an aerobic situation, enabling oxygen to enter the soil which later will affect photosynthesis rate and the growth of plant dry weight.

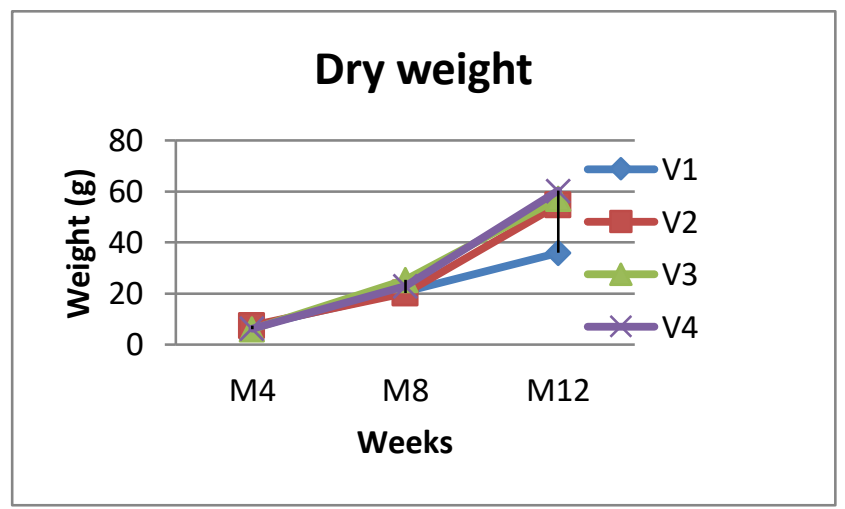

Figure 4 (a). Graph of Dry Weight of Rice Plants

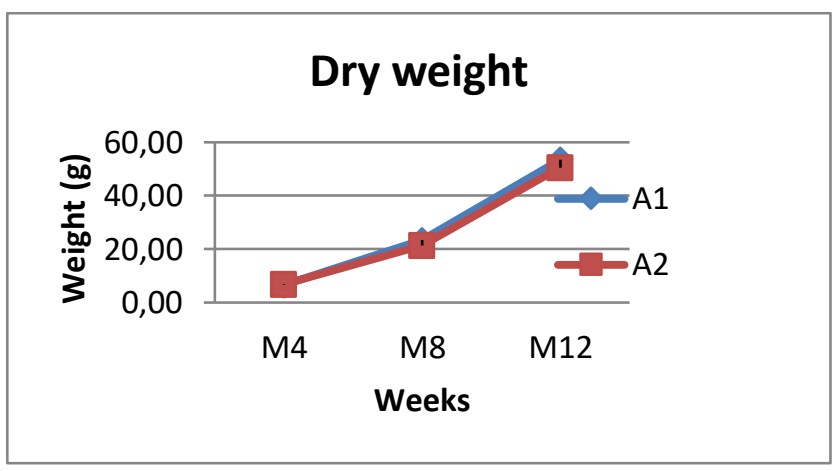

Figure 4 (b). Graph of Dry Weight of Rice Plants

$$
\begin{array}{rlrl}
\text { Note: } V 1 & =\text { Ciherang } & & \text { A1 }=\text { SRI } \\
\text { V2 } & =\text { Memberamo } & \text { A2 }=\text { Conventional } \\
\text { V3 } & =\text { Inpari } 19 & & \\
\text { V4 } & =\text { Rojolele } & &
\end{array}
$$

As shown in Table 3, the results of the rice variety of productive tillers showed an interaction between the treatment of varieties and irrigation. The treatment of SRI irrigation on Ciherang variety and conventional irrigation on Memberamo variety showed a significantly higher effect compared to the irrigation of SRI on Memberamo, SRI irrigation and conventional irrigation on Rojolele varieties. This showed that the Ciherang variety with intermittent irrigation can create an aerobic atmosphere so that it will increase the role of anaerobic microbes in the rice roots. According to [8], sufficient nitrogen will increase the number of productive stems of plants because it plays an important role as a constituent of proteins used by plants to increase the number of panicles per clump. On Memberamo variety, conventional irrigation and SRI had 14.45 productive tillers and 5.44 productive tillers respectively.

Table 3. Average productive tillers of 12 -week-old rice plants

\begin{tabular}{llllll}
\hline \multicolumn{1}{c}{ Treatment } & $\begin{array}{c}\text { Ciheran } \\
\mathrm{g}\end{array}$ & $\begin{array}{c}\text { Membera } \\
\mathrm{mo}\end{array}$ & $\begin{array}{c}\text { Inpari1 } \\
9\end{array}$ & $\begin{array}{l}\text { Rojolel } \\
\mathrm{e}\end{array}$ & $\begin{array}{c}\text { Averag } \\
\mathrm{e}\end{array}$ \\
\hline SRI & $16,47 \mathrm{a}$ & $12,35 \mathrm{bcd}$ & $\begin{array}{l}15,56 \\
\mathrm{ab}\end{array}$ & $8,75 \mathrm{~d}$ & 13,28 \\
$\begin{array}{l}\text { Convention } \\
\text { al }\end{array}$ & $\begin{array}{l}12,37 \\
\mathrm{abc}\end{array}$ & $14,45 \mathrm{a}$ & $\begin{array}{l}11,34 \\
\mathrm{abcd}\end{array}$ & $9,45 \mathrm{~cd}$ & 11,90 \\
\hline Average & 14,42 & 13,40 & 13,45 & 9,20 & $(+)$ \\
\hline Note: Numbers followed by the same letter in one row and columns show \\
no significant difference based on F test and continued with DMRT \\
$\begin{array}{l}\text { at level } \alpha=5 \% \text {. } \\
(+)=\text { there is interaction between the treatment of varieties and irrigation }\end{array}$
\end{tabular}

The results of rice root variance as seen in Table 3 showed no significant interaction between varieties and irrigation. The treatment of varieties showed the significant growth, and the irrigation treatment showed some significant differences. Of other varieties, those are Ciherang, Memberamo and Inpari 19, the longest root growth was found in Rojolele variety, which is $53.35 \mathrm{~cm}$. Varieties growing in intermittent irrigation systems had root systems that were larger in number and longer main roots compared to the deep plants. SRI method irrigation produced a root growth by $41.50 \mathrm{~cm}$ longer than the conventional method by $38.88 \mathrm{~cm}$. This showed that irrigation by stagnation could make the soil hypoxic (lack 
of oxygen) for the roots and not ideal for rice growth. Hence, the root would experience a decrease in root length

Table 4 shows the results of the variety of rice leaf area in which there was no significant interaction between varieties and irrigation. Variety treatment showed that leaf area was not significantly different. Similarly, the irrigation treatment showed that the leaf area was not significantly different. Basically, the ability of each plant leaf to produce photosynthetic products varies so that additional nutrients are needed to produce primary metabolites. The energy produced depends on the external and internal ratios of the leaf [9].

Table 4. Average root length, total root length, and leaf area of rice plants aged 12 weeks

\begin{tabular}{|c|c|c|c|}
\hline Treatment & $\begin{array}{l}\text { Root length } \\
(\mathrm{cm})\end{array}$ & $\begin{array}{c}\text { Total root } \\
\text { length }\end{array}$ & $\begin{array}{l}\text { Leaf area } \\
(\mathrm{cm} 2)\end{array}$ \\
\hline Ciherang & $36,06 \mathrm{q}$ & $127,5 \mathrm{pq}$ & $527,17 \mathrm{p}$ \\
\hline Memberamo & $38,25 \mathrm{q}$ & $326,7 p$ & $586,65 \mathrm{p}$ \\
\hline Inpari19 & $38,02 \mathrm{q}$ & $72,6 \mathrm{q}$ & $644,19 p$ \\
\hline Rojolele & $56,36 \mathrm{p}$ & $28,4 \mathrm{r}$ & $534,35 \mathrm{p}$ \\
\hline$S R I$ & $41,52 \mathrm{a}$ & $26,3 \mathrm{a}$ & $591,02 \mathrm{a}$ \\
\hline Conventional & $38,86 \mathrm{~b}$ & $57,0 \mathrm{~b}$ & $557,66 \mathrm{a}$ \\
\hline Interaction & -) & $(-)$ & $(-)$ \\
\hline
\end{tabular}

Note: Figures followed by the same letter in one column show that they are not significantly different based on the $\mathrm{F}$ and DMRT tests at the level of $\alpha=5 \%$

$(-)=$ There was no significant interaction

The results of panicle length in variety showed no significant interaction between varieties and irrigation. Variety treatment showed that panicle length was significantly different, while irrigation treatment showed no significant difference.

Table 5. Average of Rice panicle length

\begin{tabular}{lcclcc}
\hline \multirow{2}{*}{ Treatment } & $\begin{array}{c}\text { Ciheran } \\
\mathrm{g}\end{array}$ & $\begin{array}{c}\text { Membera } \\
\text { mo }\end{array}$ & $\begin{array}{l}\text { Inparil } \\
9\end{array}$ & $\begin{array}{c}\text { Rojolel } \\
\mathrm{e}\end{array}$ & $\begin{array}{c}\text { Averag } \\
\mathrm{e}\end{array}$ \\
\hline SRI & 23,91 & 25,21 & 25,37 & 41,13 & $28,91 \mathrm{a}$ \\
Convention & 23,59 & 25,87 & 25,37 & 39,37 & $28,55 \mathrm{a}$ \\
al & & & $25,37 \mathrm{q}$ & $40,25 \mathrm{p}$ & $(-)$
\end{tabular}

Note: Average followed by the same letters in one row or columns shows no significant difference on the F test and or DMRT at $\alpha=5 \%$.

$(-)=$ There was no significant interaction

The treatment of Rojolele variety showed a longer panicle growth by 39.75 compared to Inpari 19, Ciherang and Memberamo. Meanwhile, irrigation treatment showed a similar effect so that the use of SRI irrigation is sufficient for the growth of panicle length. This is in accordance with research conducted that the panicle length and number of the grains per panicle were not affected by the irrigation system, but Rojolele variety had a longer panicle length in accordance with its genetics.

\section{B. Rice Plant Physiology}

Table 6 shows the mean of harvest index, Net Assimilation Rate (NAR), Relative Growth Rate (RGR), Crop Growth Rate (CGR), and Specific Leaf Weight (SLW) of rice plants. The results of variance in these variables indicated that there was no significant interaction between varieties and irrigation, meaning that there was no mutual influence between the factors of variety and irrigation treatment on that variables. The results of variance in harvest index in the treatment of varieties showed significantly different results in contrast to the irrigation treatment. The Ciherang treatment showed the harvest index of 0.9703 significantly higher than Inpari19 and Rojolele.

Variety treatment showed that NAR was not significantly different, and so did the irrigation treatment. The difference in yield between high yield rice and low yield rice lies in the ability to accumulate the dry matter and translocation of assimilation during seed filling [10].

Variety treatment showed that RGR was not significantly different, so did the irrigation treatment. This showed that all varieties had the ability to produce dry material resulted from assimilation at initial dry weight with the same amount. On the other hand, the need for water to produce dry material resulted from assimilation at initial dry weight was sufficient.

Table 6. Average harvest index, NAR, RGR, CGR, and SLW of rice plants

\begin{tabular}{|c|c|c|c|c|c|}
\hline Treatment & $\begin{array}{c}\text { Index } \\
\text { harvest }\end{array}$ & $\begin{array}{c}\text { NAR } \\
(\mathrm{g} / \mathrm{cm} 2 / \\
\text { week })\end{array}$ & $\begin{array}{l}\text { RGR (g/g/ } \\
\text { week ) }\end{array}$ & $\begin{array}{l}\text { CGR } \\
\text { (g/cm2/ } \\
\text { week) }\end{array}$ & $\begin{array}{c}\text { SLW } \\
(\mathrm{g} / \mathrm{cm} 2 / \text { week } \\
)\end{array}$ \\
\hline Ciherang & $\begin{array}{l}0,9705 \\
\mathrm{p}\end{array}$ & $\begin{array}{l}0,0102 \\
\mathrm{p}\end{array}$ & $0,271 \mathrm{p}$ & $\begin{array}{l}0,0097 \\
\mathrm{p}\end{array}$ & $0,0078 \mathrm{p}$ \\
\hline Memberamo & $\begin{array}{l}0,9412 \\
\mathrm{pq}\end{array}$ & $\begin{array}{l}0,0083 \\
\mathrm{p}\end{array}$ & $0,264 \mathrm{p}$ & $\begin{array}{l}0,0062 \\
\mathrm{p}\end{array}$ & $0,0081 \mathrm{p}$ \\
\hline Inpari19 & $\begin{array}{l}0,9288 \\
q\end{array}$ & $\begin{array}{l}0,0124 \\
\mathrm{p}\end{array}$ & $0,361 \mathrm{p}$ & $\begin{array}{l}0,0083 \\
\mathrm{p}\end{array}$ & $0,0077 \mathrm{p}$ \\
\hline Rojolele & $\begin{array}{l}0,7841 \\
\mathrm{r}\end{array}$ & $\begin{array}{l}0,0116 \\
\mathrm{p}\end{array}$ & $0,341 \mathrm{p}$ & $\begin{array}{l}0,0082 \\
\mathrm{p}\end{array}$ & $0,0081 \mathrm{p}$ \\
\hline$S R I$ & $\begin{array}{l}0,9132 \\
\mathrm{a}\end{array}$ & $\begin{array}{l}0,0113 \\
\mathrm{a}\end{array}$ & $0,329 \mathrm{a}$ & $0,0086 \mathrm{a}$ & $0,0078 \mathrm{a}$ \\
\hline Conventional & $\begin{array}{l}0,8988 \\
\mathrm{a}\end{array}$ & $\begin{array}{l}0,0101 \\
\mathrm{a}\end{array}$ & $0,288 \mathrm{a}$ & $0,0077 \mathrm{a}$ & $0,0081 \mathrm{a}$ \\
\hline Interaction & $(-)$ & $(-)$ & $(-)$ & $(-)$ & $(-)$ \\
\hline
\end{tabular}

Note: Figures followed by the same letter in one column show that they are not significantly different based on the F and DMRT tests at the level of $\alpha=5 \%$.

$(-)=$ There was no significant interaction

The treatment of varieties showing CGR was not significantly different, so did the irrigation treatment. This showed that the treatment of several varieties had an ability to produce dry material resulted from assimilation in each unit of land area with the same amount. Whereas, the need for water to produce dry material resulted from assimilation in each unit of land area with the same amount was sufficient.

The treatment of varieties showing SLW was not significantly different, similar with the irrigation treatment showing no significant difference. This showed that the treatment of several varieties had the same leaf weight and leaf area, meaning that the plants had no differences on leaf thickness among Ciherang, Memberamo, Inpari 19, and Rojolele.

\section{Components of Yields of Rice Plant}

Table 7 shows the mean weight of grains per clump and the percentage of unfilled grains. The results of the variance in these variables indicated that there was no significant 
interaction between varieties and irrigation. It means that there was no mutual influence between the factors of variety and irrigation treatment on these variables. Variety treatment showed a different grain weight per clump and it was not similar with the irrigation treatment showing no difference. Rojolele variety showed the grain yield per clump of 40.33 grams significantly heavier than Inpari 19, Ciherang and Memberamo. This was caused by several factors including the process of filling seeds, photosynthetic production produced by plant organs that act as sources, the translocation system from source to sink and photosynthetic accumulation on the sink. The result of the filling process in rice seeds showed the balance of the three [11].

Table 7. Average grain weight per clump and $\%$ unfilled grain

\begin{tabular}{lcc}
\hline \multicolumn{1}{c}{ Treatment } & grain weight per clump (g) & unfilled grain(\%) \\
\hline Ciherang & $25,45 \mathrm{q}$ & $6,71 \mathrm{q}$ \\
Memberamo & $26,90 \mathrm{q}$ & $11,34 \mathrm{p}$ \\
Inpari19 & $27,01 \mathrm{q}$ & $10,71 \mathrm{p}$ \\
Rojolele & $43,31 \mathrm{p}$ & $12,40 \mathrm{p}$ \\
\hline SRI & $29,10 \mathrm{a}$ & $9,56 \mathrm{a}$ \\
Conventional & $27,76 \mathrm{a}$ & $11,01 \mathrm{a}$ \\
\hline Interaction & $(-)$ & $(-)$ \\
\hline
\end{tabular}

Note: Averages followed by the same letter in one column shows that they were not significantly different based on the F and DMRT at $\alpha=5 \%$.

$(-)=$ There was no significant interaction

Variety treatment showed that the percentage of unfilled grain was significantly different, while the irrigation treatment showed no significant difference. Ciherang variety showed the percentage of unfilled grain of $5.73 \%$ significantly lower than the varieties of Rojolele, Memberamo, and Ciherang.

\section{CONCLUSIONS}

The results showed that the treatment of varieties affected the physiology, growth, and weight of grain. The of rice harvest index of Ciherang variety was greater than that of Inpari 19 and Rojolele varieties. Growth was seen in the parameters of plant height, plant fresh weight, and plant dry weight. Meanwhile, the yield of rice was seen from the parameters of grain weight and the percentage of unfilled grain. The grain weight of Rojolele variety was heaviest among other varieties. The percentage of unfilled grains of Ciherang variety of rice was found the least of other varieties. Irrigation treatment and SRI methods conventionally affected the fresh weight of the plant and the length of the root, while the physiological parameters and weight of the grain showed no effect. SRI irrigation increased the growth of fresh plant weight and root length more than conventional irrigation. The number of productive tillers and the dry weight of the plants had the significant interactions between rice varieties and irrigation.

\section{ACKNOWLEDGEMENT}

Our thanks go to the Ministry of Research, Technology and Higher Education for funding this research so that it can be carried out and produce the output of this publication's text.

\section{REFERENCES}

[1] Cantrell, R. P. 2000. Foreword. In Redesigning the Rice Photosynthesis to Increase Yield. IRRI. Los Banos. P. 5

[2] BPS. 2014. Badan Pusat Statistik. https://www.bps .go. id/index.php accessed on December 17, 2016

[3] Armansyah, Sutoyo, and Angraini. R. 2009. Pengaruh periode pengenangan air terhadap pembentukan jumlah anakan pada tanaman padi (Oryza Satifa) dengan metode SRI (The System of Rice Intensification).Research Report Yunior Lecturers. Faculty of Agriculture Andalas University. Padang.

[4] Sato, S. Dan N. Uphoff. 2006. Raising Factor Productivity in Irrigated Rice Production: Opportunities with The System of Rice Intensification. DISIMP

[5] Berkelaar, D. 2008. System of Rice Intensification (System of Rice Intensification). Translation Indro Surono. http://elsppat.or.id/download/file/SRI echo \% 20note .htm. retrieved may 9,2015

[6] Uphoff, N., S. Rafalaby, J. R. Darsana. 2002. What is the System of Rice Intensification

[7] BBPADI. 2015. Balai Besar Penelitian Tanaman Padi http://bbpadi.litbang. pertanian.go.id/ accessed on June 1, 2016

[8] Siregar. 1981. Budidaya Tanaman Padi di Indonesia. Sastra Hudaya. Jakarta

[9] Fahn A. 1982. Anatomi Tumbuhan. Penerjemah: Soediarto A, Koesoemaningrat, Natasaputra, Akmal. Gadjah Mada University. Yogyakarta

[10] Miah, M.N.H., T. Yoshida, Y. Yamamoto, Y. Director. 1996. Characteristics of dry matter production and partitioning of dry matter in high yielding spring dwarf indica and japonica indica hybrid rice varieties 1. JPN. J. Crop Sci. 65:672-685.

[11] Sumardi, Kasli, M. Kasim, A. Sharif, and N. End. 2007. The Response of rice cultivated in aerobic technique and the granting of organic materials. Agrosia journal 10 (1): 65-71. 